\title{
Teachers' Perspectives On Teaching And Learning Strategies In Undergraduate Engineering Courses
}

\author{
Samoara Viacelli da Luz \\ Universidade Tecnológica Federal do Paraná- Pato Branco \\ Herivelto Moreira \\ Universidade Tecnológica Federal do Paraná - Curitiba
}

\begin{abstract}
The objective of this article was to identify what are the teaching strategies most used by teachers of undergraduate engineering courses from three campus of a public university in southern Brazil. The concepts used were based on studies conducted by numerous national and international authors in higher education pedagogical area, and specifically in engineering education. The literature proposes several teaching strategies which allow student's active participation, autonomy, the ability to discuss and solve problems, among other characteristics necessary for the future engineer, in order to overcome a teacher-centered approach focused on memorization. The research methodology used was a mixed sequential explanatory design that consisted of two distinct phases: a first phase with a quantitative approach and a second phase with a qualitative approach. The main results show that "lectures" are still the most used teaching strategies. In relation to the other teaching strategies proposed in the literature, the teachers demonstrated different forms of understanding and application, making it difficult to verify the frequency of use.
\end{abstract}

Keywords: Higher Education, Engineering Education, Teaching Strategies, Engineer Training.

\section{INTRODUCTION}

Several authors, both national and international, have devoted themselves to the study of engineering education. In these studies, several questions are analyzed, among which the teaching strategies used by teachers in classroom. In relation to the methodological issues in engineering education in Brazil, two areas of study were investigated: one that deals with teaching methodology in higher education in general (Abreu \& Masetto, 1980; Anastasiou, 1998; Anastasiou \& Alves, 2006; Castanho, 2000), and the area of engineering education (Bazzo, Pereira \& Linsingen, 2000; Belhot, 2005; Villas-Boas, Mattasoglio Neto, et al., 2012). In analyzing both areas in the literature it was found that studies in the area of higher education methodology do not address the specificities of engineering education, and the area of engineering education, for the most part, does not address teaching strategies from a pedagogical perspective as it tends to analyze experiences of applying teaching strategies or specific teaching resources for a particular content or subject matter. The relevance of these studies is indisputable, but they do not make a broader diagnosis of all possible teaching strategies to be used by teachers in undergraduate engineering courses.

Nassif (2013) points out that there are few studies focused on pedagogical issues in engineering teaching, considering the current context of new values, which require a multiplicity of functions of the engineer. In addition, Cunha \& Leite (1994 and 1996, apud Broilo, 2011), found that intervention actions aimed at improving the quality of higher education can no longer be triggered without the construction of scientifically produced 
knowledge about reality, taking into account that the problems of pedagogical practice are closely related to the epistemological field in which the professions are inserted.

From these reflections, the objective of this article was to identify which teaching strategies are most used by teachers of Civil Engineering, Computing, Electrical, Electronics and Mechanics undergraduate courses of three campus of a public university in southern Brazil.

\section{TEACHING AND LEARNING STRATEGIES}

Several studies on higher education in Brazil (Anastasiou, 1998; Anastasiou \& Alves, 2006; Barbosa \& Moura, 2013; Bazzo, Pereira \& Linsingen, 2000; Carvalho, Porto \& Belhot, 2001; Moreira, Luz et al., 2015) reflect on the need to broaden the discussions about improving the quality of teaching, and in general, the same authors point out that most of the time, the difficulty is not related to the knowledge that the teachers have about the contents to be taught, but to aspects related to the pedagogical knowledge, that is, the appropriate way to use the most pertinent strategies to deliver the contents.

In this sense, some authors in the area of education (Gil, 2013; Anastasiou, 2001) consider that we still find in Brazilian higher education, strong remnants of the traditional Jesuit methodology guiding the action of teachers, despite so many decades have passed. In this type of approach the learning process is centered on the teacher who transmits the contents to the students, who in turn must passively assimilate the information. Intelligence is associated with memorization, so that the teaching work is directed to the maintenance of the student's attention and to the explanation of the content, partly the teacher's "property", which transmits it in scheduled doses and sessions, in a basically textual and linear way. Students, in turn, receive the teachings without much interest and often, not knowing what to do with them (Silva \& Cecílio, 2007).

Lecture has so far remained the dominant form of academic teaching in spite of continued attacks, critiques and intentions to suppress it and replace it with more efficient methods and procedures. Although, lecture is efficient in the transfer of knowledge, is not sufficient for deeper understanding, problem solving, creative work, and similar. In the effort to overcome the traditional teaching methodology, new methodological proposals are being suggested to help develop critical thinking, self-confidence, a sense of responsibility and initiative, the ability to learn, communicate, develop teamwork, make decisions and solve problems and conflicts (Gonçalves, 2008).

One proposal that seeks to overcome traditional pedagogy is the active learning approach. Although this approach has been in use for several decades in many countries, in Brazil it is still not a reality in many higher education institutions. This teaching methodology assumes the active involvement of the student in the process of learning, reading, writing, asking, discussing or problem solving, and project development. In addition, the student should perform mental tasks of high cognitive level, such as analysis, synthesis, and evaluation (Barbosa \& Moura, 2013). In short, active learning involves students to do and think about what they are doing (Bonwell \& Eison, 1991).

According to Felder and Brent (2004 apud Campos et al., 2012), active learning consists of any activity that results in student engagement about what is being presented. It involves individual or group work to answer questions, solve small problems, start solving more complex problems, brainstorming or think about issues presented. 
Bonwell \& Eison (1991, p. 2) points out some of the main characteristics associated to active learning: a) integrate thought and practical activities; b) enable varied learning styles; c) promote cognitive interaction with the others, whether adults or peers; d) emphasize exploration of attitudes and values; e) support readiness to carry out tasks and motivation to learn; g) develop higher-level cognitive processes; foster reflection and metacognitive activity; enable observation and monitoring of students and facilitate immediate feedback from teachers (e.g. their prior knowledge and learning styles).

Active learning and engineering education, according to Graaff and Christensen's thinking (2004, apud Villas-Boas, Mattasoglio Neto, 2012, p. 64), form a natural pair because "the engineer is educated to design and build solutions to real-world problems. Originally, the act of educating, in engineering, used to have very close links with its practice, but gradually engineering education became more and more theory-based".

Some authors who study active learning methods applied in engineering education (Chickering \& Gamson, 1987; Morais, 2009; Pereira, Schmitt \& Dias, 2007) argue that students should do more than just listen. They should read, write, discuss, or engage in problem solving. For VillasBoas, Mattasoglio Neto, et al. (2012, p. 63),

the reformulation of the preparation of the engineer's professional profile puts [...] demands on new methodologies, differentiated pedagogical positions and a more consistent vision of the teaching-learning relationship. In this situation, the expression "active learning", or "active learning methods", has received growing attention from educators as one of the possible answers to the new educational demands.

The focus of the teaching-learning process, which should move from teaching (having the teacher as the center of the process), to learning (having the student as the center of the process), requires changes, especially by the teachers, because they need to master new pedagogical strategies in order to improve the quality of their teaching.

Considering the above discussions, which revolve around the search for the improvement of engineering education, it is necessary to look to the teaching strategies which compose the daily life of the classroom, giving shape and concretizing the moment of teaching. In order to list the various strategies used in higher education, a synthesis (Table 1) was elaborated, based on publications of researchers from the areas of higher education didactics and engineering education, whose purpose is to present definitions of these strategies. However, it is pertinent to point out that the presented strategies are not the only ones used in undergraduate engineering courses, and there may also be variations of nomenclature, form of application, etc. 
Table 1 - Teaching strategies used in higher education and in engineers' training

\begin{tabular}{|c|c|}
\hline Teaching Strategies & Definition \\
\hline $\begin{array}{l}\text { Virtual Learning } \\
\text { Enviroments }\end{array}$ & $\begin{array}{l}\text { Virtual environment that allows the administration, storage and availability of } \\
\text { contents and documents (files); the interaction between students and teachers } \\
\text { through forums, chat rooms, collaborative texts, etc.; and the accomplishment } \\
\text { of evaluative processes and monitoring student's activities. }\end{array}$ \\
\hline Problem-based learning & $\begin{array}{l}\text { Active didactic procedure, in which the students are placed before a new } \\
\text { problem situation that has not been learned and to which they must present a } \\
\text { solution or suggestion of solution, according to the nature of the proposed } \\
\text { problem, using techniques already learned. }\end{array}$ \\
\hline $\begin{array}{l}\text { Group discussion } \\
\text { activities }\end{array}$ & $\begin{array}{l}\text { A strategy that seeks to break down a point of view, subjecting it to } \\
\text { questioning and analysis. Discussion of a theme/problem by students which } \\
\text { can be developed in a number of ways. }\end{array}$ \\
\hline Lecture & $\begin{array}{l}\text { Teaching time occupied wholly or mainly by a teacher-centered exposition. } \\
\text { The teacher presents answers without the students asking him or her } \\
\text { questions. Students may have the opportunity to ask or participate in a small } \\
\text { discussion, but in general they do no more than listen and take notes. }\end{array}$ \\
\hline Dialogic Lecture & $\begin{array}{l}\text { Presentation of content by the teacher, with the active participation of } \\
\text { students, whose prior knowledge must be considered, and may even be taken } \\
\text { as a starting point. The teacher seeks to establish a relationship of exchange of } \\
\text { knowledge and experiences with the students and uses the dialogue to cause } \\
\text { the students to question, interpret and discuss the object of study. }\end{array}$ \\
\hline $\begin{array}{l}\text { Demonstrative practice } \\
\text { class }\end{array}$ & $\begin{array}{l}\text { A strategy often held in laboratories or in other specific environments, } \\
\text { centered on the teacher, for demonstration of contents, theories, procedures, } \\
\text { etc. }\end{array}$ \\
\hline Executive practice class & $\begin{array}{l}\text { Held in the laboratory or other specific environments in which students } \\
\text { participate actively, developing activities, operating equipment, under the } \\
\text { guidance of the teacher. }\end{array}$ \\
\hline Case study & $\begin{array}{l}\text { Teacher brings to the students the report of a real case, fictitious or adapted } \\
\text { from reality, which is analyzed thoroughly and objectively from concepts } \\
\text { already studied. }\end{array}$ \\
\hline Games & Use of games as didactic resource. \\
\hline $\begin{array}{l}\text { Workshop, round table, } \\
\text { panel, forum, symposium }\end{array}$ & $\begin{array}{l}\text { Set of varied activities that aim to meet people, students and/or specialists, in } \\
\text { order to study, debate and work towards the knowledge or deepening of a } \\
\text { theme. }\end{array}$ \\
\hline $\begin{array}{l}\text { Guided reciprocal peer } \\
\text { questioning }\end{array}$ & $\begin{array}{l}\text { The teacher makes a brief statement on a subject. It then gives the students a } \\
\text { list of essential points on the subject. The students, individually, elaborate } \\
\text { questions on the content that, not necessarily, they can answer. They then } \\
\text { discuss group issues. In the end, the teacher broadens the discussion of the } \\
\text { most relevant issues with the whole class. }\end{array}$ \\
\hline Debates & $\begin{array}{l}\text { Debates can be an effective and engaging way for students to analyze different } \\
\text { concepts and to develop critical thinking and public speaking skills. They are } \\
\text { also useful strategies for achieving greater participation in class and for } \\
\text { discussing controversial issues in a structured environment. }\end{array}$ \\
\hline Dramatization & $\begin{array}{l}\text { Representation, theatrical presentation, in which, from a given situation, the } \\
\text { students set up a "theater". It can contain explanation of ideas, concepts, } \\
\text { arguments etc. }\end{array}$ \\
\hline Inquiry-based learning & $\begin{array}{l}\text { Inquiry-based learning is a research-based strategy that actively involves } \\
\text { students in the exploration of the content, issues, and questions surrounding a } \\
\text { curricular area or concept. The activities and assignments can be designed in a } \\
\text { way that students work individually or together to solve problems involving } \\
\text { both in-class work and fieldwork. }\end{array}$ \\
\hline $\begin{array}{l}\text { Just-in-time teaching } \\
\text { (JiTT) }\end{array}$ & $\begin{array}{l}\text { Students, before classes answer to questions about the content to come, } \\
\text { formulated by the teacher. Questions can be made available in a virtual } \\
\text { environment. The teacher uses the students' responses to prepare class } \\
\text { activities. }\end{array}$ \\
\hline Project-based Learning & $\begin{array}{l}\text { Project-based learning involves deep learning, as it focuses on real world } \\
\text { problems and challenges and relies on problem solving, decision making and } \\
\text { investigative skills. Project-based learning begins with the end product or } \\
\text { presentation in mind that requires learning specific knowledge and concepts, }\end{array}$ \\
\hline
\end{tabular}




\begin{tabular}{|c|c|}
\hline & $\begin{array}{l}\text { thus creating a context and reason to learn and understand the information } \\
\text { and concepts. }\end{array}$ \\
\hline Field study & $\begin{array}{l}\text { Study of the natural and social context in which the student enters, aiming at a } \\
\text { specific problem in an interdisciplinary way. It creates conditions for the } \\
\text { contact with reality; it facilitates the acquisition of knowledge directly, through } \\
\text { the lived experience. }\end{array}$ \\
\hline Text study & $\begin{array}{l}\text { Exploring an author's ideas, from the critical study of a text, unveiling its } \\
\text { structure, its objective, and perceiving the resources used by the author for the } \\
\text { transmission of the message. }\end{array}$ \\
\hline Independent Study & $\begin{array}{l}\text { To study under the guidance and directivity of the teacher, aiming to remedy } \\
\text { specific difficulties. This study can be developed in or outside the classroom } \\
\text { and can replace the presentation of the content by the teacher. }\end{array}$ \\
\hline Exercise Solving & $\begin{array}{l}\text { It is based on the use of skills or techniques learned, that is, transformed into } \\
\text { automated routines as a consequence of continuous practice. It is limited to } \\
\text { exercising a technique in situations or tasks that can be solved by the usual } \\
\text { means. Priorizes the memorization of rules, formulas, equations and } \\
\text { algorithms. }\end{array}$ \\
\hline $\begin{array}{l}\text { Thinking-aloud pair } \\
\text { problem solving }\end{array}$ & $\begin{array}{l}\text { In pairs, a student is the solver of a problem launched by the teacher and the } \\
\text { other, the questioner. The solver presents the solution step by step. The } \\
\text { questioner notes errors detected. The teacher asks questions to the groups to } \\
\text { know at what stage is the solution of the problem. }\end{array}$ \\
\hline Seminars & $\begin{array}{l}\text { Study of a theme from different sources to be studied and systematized by a } \\
\text { group of participants, under the guidance of the teacher, aiming at obtaining an } \\
\text { overview of the subject matter. }\end{array}$ \\
\hline Simulations & $\begin{array}{l}\text { Emulation of a real situation, in which the student must "work" searching for } \\
\text { solutions or analyzing component variables etc. The simulations can be done } \\
\text { through equipment, computers, simulated jury, etc.) }\end{array}$ \\
\hline Softwares & $\begin{array}{l}\text { They have a didactic character and are specially developed to help the student } \\
\text { to build knowledge related to a didactic content, with or without the mediation } \\
\text { of a teacher. They can be classified in tutorials, exercise or practice, } \\
\text { demonstration, simulation, game and monitoring. }\end{array}$ \\
\hline Brainstorming & $\begin{array}{l}\text { Students express orally, in words or short sentences, everything that comes to } \\
\text { mind on a given topic, without bothering to "censor" these ideas. There is no } \\
\text { right or wrong. Anything that is raised will be considered, and a further } \\
\text { explanation will be requested if necessary. Concomitant with these activities, } \\
\text { someone will write down everything that is said, on the board or on a paper. }\end{array}$ \\
\hline $\begin{array}{l}\text { Cooperative note-taking } \\
\text { pairs }\end{array}$ & $\begin{array}{l}\text { In pairs, students share their notes, so that everyone can improve their notes, } \\
\text { synthesis, about the content being treated. }\end{array}$ \\
\hline Technical visits & $\begin{array}{l}\text { Students participate in excursions, visits to industries, companies, } \\
\text { environments etc. }\end{array}$ \\
\hline Concept maps & $\begin{array}{l}\text { Concept maps are visual representations of the relationships between } \\
\text { concepts. Concepts are placed in nodes (often, circles), and the relationships } \\
\text { between indicated by labeled arrows connecting the concepts. To have } \\
\text { students create a concept map, identify the key concepts to be mapped in small } \\
\text { groups or as a whole class. }\end{array}$ \\
\hline Portfolios & $\begin{array}{l}\text { The portfolio is an open-ended and un-graded task designed to explore } \\
\text { teaching from many different vantage points. It is organized as a dynamic } \\
\text { assessment task, not simply a static end product. }\end{array}$ \\
\hline
\end{tabular}

\section{Study Design}

\section{METHODOLOGY}

The researchers used a mixed methods approach (Tashakkori \& Teddlie, 2003), which is a procedure for collecting, analyzing and mixing or integrating both quantitative and qualitative data at some stage of the research process within a single study (Creswell, 2005). The rationale for mixing both types of data is that neither quantitative nor qualitative methods are sufficient by themselves to capture the trends and details of situations. When used in combination, quantitative and qualitative methods complement each other and provide a more complete picture of the research problem (Green, Caracelli, \& Graham, 1989; Johnson \& Turner, 2003). 
This study used a sequential explanatory mixed methods design, consisting of two distinct phases (Creswell, Plano Clark, Guttman, and Hanson, 2003). In this design, the quantitative (numeric) data is collected and analyzed first, while the qualitative (text) data is collected and analyzed second in sequence, and helps explain, or elaborate on the quantitative results obtained in the first phase. The priority (Creswell et al., 2003) in the study was given to the qualitative approach, because it focused on in-depth explanations of the results obtained in the first, quantitative, phase. The results of the quantitative and qualitative phases were integrated (Creswell et al., 2003) during the discussion of the outcomes of the entire study (see Fig. 1) for a diagram of the mixed methods sequential explanatory design procedures in the study).

Figura 1 - Diagram of the mixed sequential explanatory design

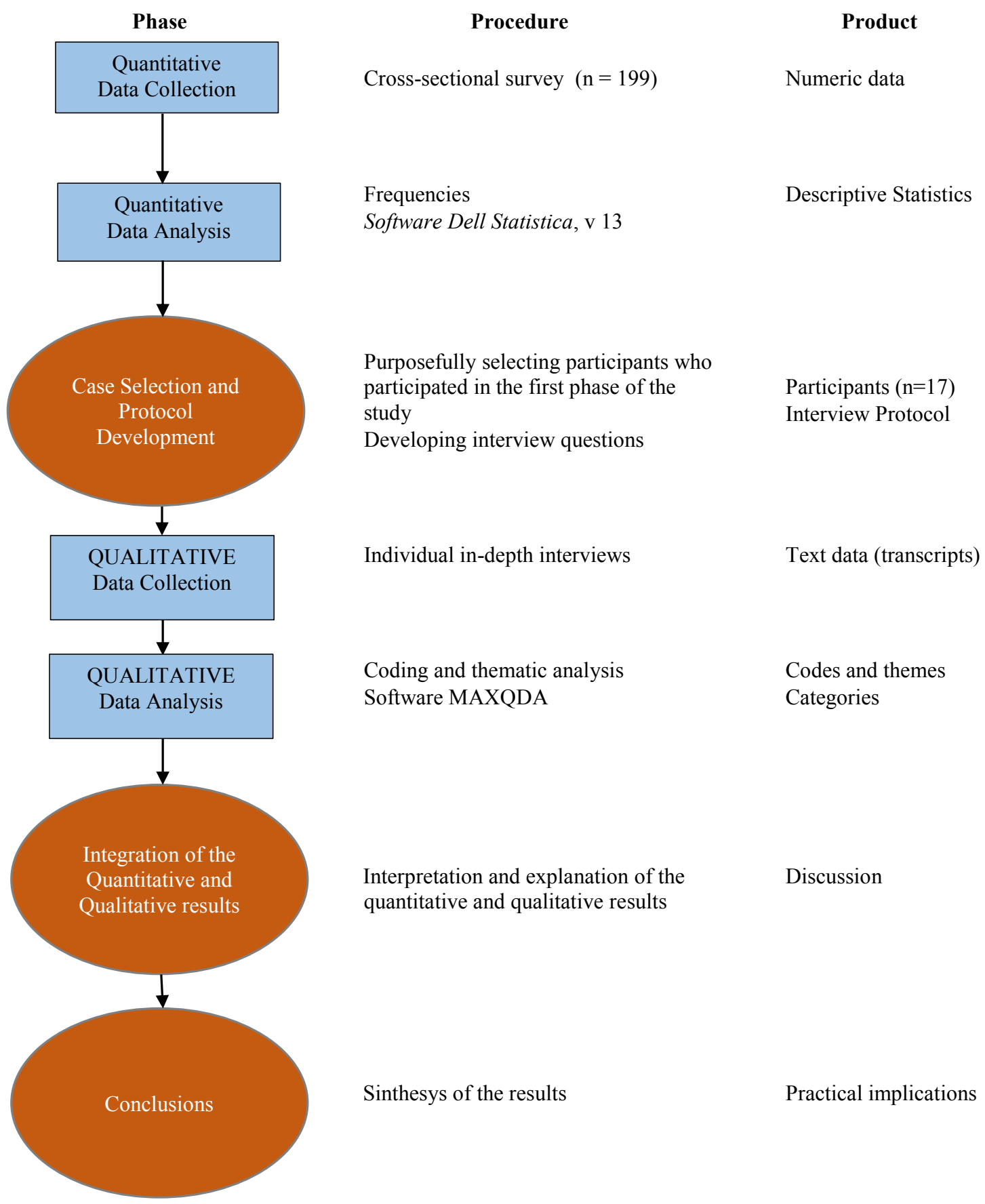

Source: Creswell \& Plano Clark (2013). 


\section{Target Population}

The target population in this study was 396 professors of professional and specific subjects of the Civil, Computing, Electrical, Electronics and Mechanics undergraduate engineering courses of three campuses of a public university in southern Brazil. The sample of the quantitative phase was composed by 199 teachers, selected through non-probabilistic sampling by trial. The participants of the qualitative phase were 17 teachers selected purposefully, with reference to the participants of the quantitative phase and using the sampling strategy of maximum variation.

\section{Data Collection}

\section{QUANTITATIVE PHASE}

In the first phase of the study, quantitative, the data were collected from a cross-sectional survey, using as a research instrument a closed questionnaire. The questionnaire applied, an adaptation of the instrument used by Moreira et al. (2012), is composed of three Likert-type scales, which aim to evaluate different aspects related to teaching strategies, evaluation and acquisition of didactic-pedagogical skills.

In this article, we will report only the results obtained with the evaluation scale of teaching strategies (ESTS), composed of 6 points, with anchors in: 0 (Not applicable) 1 (Never), 2 (Few Times), 3 (Sometimes), 4 (Frequently) and 5 (Always). The 33 variables that make up the scale are teaching strategies based on the publications of several researchers in the area of didactics of higher education and the area of engineering education (Abreu \& Masetto, 1980; Anastasiou \& Alves, 2006; Barbosa \& Moura, 2013; Ghelli, 2004; Gil, 2013; Godoy, 2000; Villas-Boas, Mattasoglio Neto, et al., 2012).

The questionnaire was applied in the first half of 2015 to a non-probabilistic sample by trial, composed of 199 teachers. From the answers indicated in the questionnaires, the results were obtained through descriptive statistics performed in the software Dell Statistica version 13.

\section{Data Analysis}

Univariate statistical procedures were used to analyze the survey data. Survey demographic information and the participants' answers to separate items on the evaluation scale of teaching strategies were analyzed using frequency counts.

\section{QUALITATIVE PHASE}

The second phase of the study was characterized as qualitative. According to Moreira \& Caleffe (2008, p. 73), the qualitative research "explores the characteristics of individuals and scenarios that cannot be easily described numerically. The data is often verbal and is collected by observation, description and recording". The qualitative phase of the study in an explanatory sequential mixed design, intended to assist in the interpretation and explanation of the questions arising from the initial quantitative results (Creswell \& Plano Clark, 2013; Sampieri, Collado \& Lucio, 2013).

\section{Interview Protocol Development}

The interview protocol was elaborated from the observation of the results obtained in the quantitative phase, in order to formulate questions that aimed to know or understand in-depth what had already been answered objectively in the quantitative phase. The interview protocol consisted of five blocks of questions: 1 - Initial questions; 2 - Teaching process; 3 - Teaching strategies; 4 - Evaluation strategies; 5 - Acquisition of didactic-pedagogical skills. In this article we will discuss only the answers that refer to the use of teaching strategies. 


\section{Data collection}

The technique to collect data was the semi-structured individual interview. Interviews were conducted with 17 teachers who participated in the first phase of the study and who expressed an interest in participating in the second phase. A purposive sample was used to select participants, and the sampling strategy used was the maximum variation, whose objective is "to capture the various variations in the sample and to identify common patterns" (Moreira \& Caleffe, 2008, p.175). Each interview was audio taped and transcribed verbatim.

\section{Data analysis}

To analyze the qualitative data, the comparative constant method of data analysis were used (Charmaz, 2009; Leite, 2015). The method involves the following steps: a) reading and rereading the transcripts of interviews and notes; b) creation of codes with the software MAXQDA 12; c) comparisons and groupings of codes in preliminary categories of similar opinions; d) connection of preliminary categories; e) interpretation and discussion of categories.

\section{Quantitative Phase}

\section{RESULTS}

\section{Demographic Information}

The study participants were compared on the following demographic characteristics: campus, age, gender, kind of degree, and academic qualification. The typical participants were: between 30 and 59 years, predominantly man (85\%), as for career stage $30 \%$ (59) early career, $21 \%$ (41) mid-career, and 49\% (98) late career, 94\% have master and/or doctorate degree (see Table 1).

Table 1 - Demographic characteristics of the quantitative sample

\begin{tabular}{llr}
\hline Item & Category & $\begin{array}{c}\text { Quantitative } \\
\text { Phase } \\
(\mathbf{n = 1 9 9 )}\end{array}$ \\
\hline \multirow{2}{*}{ Campus } & Campus 1 & $101(51 \%)$ \\
& Campus 2 & $71(36 \%)$ \\
& Campus 3 & $27(14 \%)$ \\
Gender & Female & $30(15 \%)$ \\
& Male & $169(85 \%)$ \\
Career Stage & Early Career (5 years or less) & $59(30 \%)$ \\
& Mid Career (6 to 12 years) & $42(21 \%)$ \\
Kind of Degree & Late Career (13 years or more) & $98(49 \%)$ \\
& & $186(93 \%)$ \\
Academic Qualification & Engineering & $13(7 \%)$ \\
& Technology & $12(6 \%)$ \\
& & $57(29 \%)$ \\
\end{tabular}

\section{Scale Items Frequencies Analysis}

Table 2 shows the frequency of teachers' responses to the most used teaching strategies in the classroom. It is possible to observe that the most used teaching strategies are: "virtual learning environments", "lecture", "dialogic lecture", and "exercise solving" (traditional teaching methods). The least used strategies are: "dramatization", "games", "guided reciprocal peer questioning" and "discussion lists via computerized means". 
Tabela 2 - Frequency of use the teaching strategies $(n=199)$

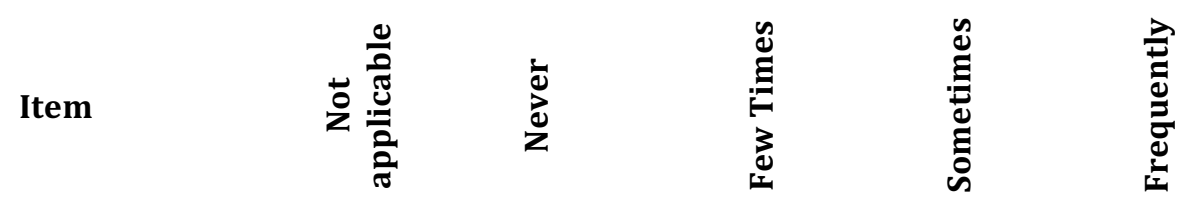

$\frac{2}{3}$

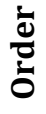

\begin{tabular}{|c|c|c|c|c|c|c|c|}
\hline Virtual Learning Enviroments & $1(0 \%)$ & $7(4 \%)$ & $9(5 \%)$ & $14(7 \%)$ & $44(22 \%)$ & $124(62 \%)$ & 1 \\
\hline Lecture & $1(0 \%)$ & $3(2 \%)$ & $12(6 \%)$ & $31(16 \%)$ & $78(39 \%)$ & $74(37 \%)$ & 2 \\
\hline Dialogic Lecture & $0(0 \%)$ & $2(1 \%)$ & $8(4 \%)$ & $40(20 \%)$ & $90(45 \%)$ & $59(30 \%)$ & 3 \\
\hline Exercise Solving & $6(3 \%)$ & $8(4 \%)$ & $14(7 \%)$ & $24(12 \%)$ & $65(33 \%)$ & $82(41 \%)$ & 4 \\
\hline Executive Practice Class & $6(3 \%)$ & $14(7 \%)$ & $15(8 \%)$ & $24(12 \%)$ & $66(33 \%)$ & $74(37 \%)$ & 5 \\
\hline Problem Based Learning & $2(1 \%)$ & $8(4 \%)$ & $17(9 \%)$ & $42(21 \%)$ & $82(41 \%)$ & $48(24 \%)$ & 6 \\
\hline Demonstrative Practice Class & $9(4 \%)$ & $23(12 \%)$ & $21(10 \%)$ & $43(22 \%)$ & $55(28 \%)$ & $48(24 \%)$ & 7 \\
\hline Softwares & $9(4 \%)$ & $32(16 \%)$ & $27(14 \%)$ & $32(16 \%)$ & $38(19 \%)$ & $61(31 \%)$ & 8 \\
\hline Teaching by Projects & $4(2 \%)$ & $20(10 \%)$ & $29(15 \%)$ & $48(24 \%)$ & $60(30 \%)$ & $38(19 \%)$ & 9 \\
\hline $\begin{array}{l}\text { Out-of-class Guidance by } \\
\text { Computerized Means }\end{array}$ & $4(2 \%)$ & $25(12 \%)$ & $35(18 \%)$ & $45(23 \%)$ & $50(25 \%)$ & $40(20 \%)$ & 10 \\
\hline Case Study & $5(2 \%)$ & $24(12 \%)$ & $40(20 \%)$ & $52(26 \%)$ & $47(24 \%)$ & $31(16 \%)$ & 11 \\
\hline Inquiry-based Learning & $3(1 \%)$ & $15(7 \%)$ & $51(26 \%)$ & $56(28 \%)$ & $51(26 \%)$ & $23(12 \%)$ & 12 \\
\hline Simulation & $18(9 \%)$ & $63(32 \%)$ & $15(7 \%)$ & $37(19 \%)$ & $27(13 \%)$ & $39(20 \%)$ & 13 \\
\hline Seminars & $5(2 \%)$ & $51(26 \%)$ & $42(21 \%)$ & $47(24 \%)$ & $34(17 \%)$ & $20(10 \%)$ & 14 \\
\hline Independent Study & $5(2 \%)$ & $39(20 \%)$ & $46(23 \%)$ & $56(28 \%)$ & $38(19 \%)$ & $15(8 \%)$ & 15 \\
\hline Group Discussions Activities & $16(8 \%)$ & $62(31 \%)$ & $46(23 \%)$ & $31(16 \%)$ & $30(15 \%)$ & $14(7 \%)$ & 16 \\
\hline Themes Debates & $12(6 \%)$ & $52(26 \%)$ & $53(27 \%)$ & $45(23 \%)$ & $27(13 \%)$ & $10(5 \%)$ & 27 \\
\hline Group Dynamics & $12(6 \%)$ & $73(37 \%)$ & $47(24 \%)$ & $31(15 \%)$ & $24(12 \%)$ & $12(6 \%)$ & 18 \\
\hline Conceptual Maps & $8(4 \%)$ & $86(43 \%)$ & $39(20 \%)$ & $33(17 \%)$ & $21(10 \%)$ & $12(6 \%)$ & 19 \\
\hline Texts Studies & $12(6 \%)$ & $61(31 \%)$ & $54(27 \%)$ & $40(20 \%)$ & $20(10 \%)$ & $12(6 \%)$ & 20 \\
\hline Technical Visits & $7(3 \%)$ & $81(41 \%)$ & $50(25 \%)$ & $33(17 \%)$ & $19(10 \%)$ & $9(4 \%)$ & 21 \\
\hline $\begin{array}{l}\text { Workshop, Panel Discussion, } \\
\text { Forum, Symposium }\end{array}$ & $14(7 \%)$ & $101(51 \%)$ & $36(18 \%)$ & $26(13 \%)$ & $18(9 \%)$ & $4(2 \%)$ & 22 \\
\hline Brainstorming & $19(10 \%)$ & $93(47 \%)$ & $40(20 \%)$ & $26(13 \%)$ & $12(6 \%)$ & $9(4 \%)$ & 23 \\
\hline Field Study & $16(8 \%)$ & $90(45 \%)$ & $49(25 \%)$ & $25(13 \%)$ & $13(6 \%)$ & $6(3 \%)$ & 24 \\
\hline Minute Paper & $2(1 \%)$ & $88(44 \%)$ & $56(28 \%)$ & $34(17 \%)$ & $14(7 \%)$ & $5(3 \%)$ & 25 \\
\hline $\begin{array}{l}\text { Thinking-aloud Pair Problem } \\
\text { Solving (TAPPS) }\end{array}$ & $10(5 \%)$ & $126(63 \%)$ & $20(10 \%)$ & $28(14 \%)$ & $6(3 \%)$ & $9(5 \%)$ & 26 \\
\hline Just-in-time Teaching & $6(3 \%)$ & $113(57 \%)$ & $37(19 \%)$ & $29(14 \%)$ & $8(4 \%)$ & $6(3 \%)$ & 27 \\
\hline Cooperative Note-taking Pairs & $11(6 \%)$ & $137(69 \%)$ & $19(10 \%)$ & $18(9 \%)$ & $9(4 \%)$ & $5(2 \%)$ & 28 \\
\hline Portfolio & $29(15 \%)$ & $117(59 \%)$ & $29(15 \%)$ & $11(5 \%)$ & $5(2 \%)$ & $8(4 \%)$ & 29 \\
\hline $\begin{array}{l}\text { Discussion Lists via } \\
\text { Computerized Means }\end{array}$ & $11(6 \%)$ & $133(67 \%)$ & $30(15 \%)$ & $14(7 \%)$ & $8(4 \%)$ & $3(1 \%)$ & 30 \\
\hline $\begin{array}{l}\text { Guided Reciprocal Peer } \\
\text { Questioning }\end{array}$ & $9(5 \%)$ & $124(62 \%)$ & $37(19 \%)$ & $20(10 \%)$ & $5(2 \%)$ & $4(2 \%)$ & 31 \\
\hline Games & $31(16 \%)$ & $137(69 \%)$ & $17(9 \%)$ & $7(3 \%)$ & $6(3 \%)$ & $1(0 \%)$ & 32 \\
\hline Dramatization & $43(22 \%)$ & $136(68 \%)$ & $11(6 \%)$ & $8(4 \%)$ & $1(0 \%)$ & $0(0 \%)$ & 33 \\
\hline
\end{tabular}


It is also possible to observe in Table 3 that most teaching strategies, for example, "Portfolio", "Cooperative Note-taking Pairs", "Just-in-time Teaching", "Thinking-aloud Pair Problem Solving" (TAPPS), "Minute Paper", "Field Study", "Brainstorming", "Workshop, Panel Discussion, Forum, Symposium”, “Technical Visits”, “Texts Studies”, “Conceptual Maps”, “Group Dynamics", "Themes Debates", "Group Discussions Activities", "Independent Study", "Seminars", "Simulation", "Inquiry-based Learning", "Case Study", "Out-of-class Guidance by Computerized Means", "Teaching by Projects", and "Softwares" are strategies "few times" or "never" used by the teachers.

\section{DISCUSSION}

The results show that teaching strategies that can provide greater interaction and active student participation in the teaching process through computerized resources are not widely used. Although $62 \%$ of the respondents indicated that they always use "virtual learning environments", in general, teachers' use of this strategy is limited, in most cases, mainly for receiving and sending materials and establishing contact with the students, to the detriment of the use of other resources made available by virtual environments, such as lists of discussions, chats, among others.

"Lecture" (76\%) and "dialogic lecture" (75\%), are the most used strategies. However it is important to point out that the dialogic lecture has not served to replace or to overcome the lecture, as proposed by authors such as Anastasiou \& Alves (2006) and Ghelli (2004). In this sense, the dialogic lecture is a strategy used concomitantly to lecture or the teachers can not differentiate one strategy from the other.

The "exercise solving" strategy is "frequently" or "always" used by 74\% of respondents. This strategy, according to authors in the area of higher education didactics (Clement \& Terrazzan, 2011; Conceição \& Gonçalvez, 2003; Echeverría \& Pozo, 1998) is based on the use of automated routines as a consequence of a continuous practice limited to exercise a technique in situations or tasks that can be solved by the usual means. By prioritizing the memorization of rules, formulas, equations, and algorithms, this strategy is often associated with traditional pedagogy.

Strategies such as "executive practice class", "problem-based learning" and "demonstrative practice class", considered by researchers in the areas of technological education and engineering education (Angelo \& Loula et al., 2014; Villas-Boas, Mattasoglio Neto et al.) as important to provide the development of critical thinking, the ability to solve problems in unusual situations, adaptability to change, concept learning, teamwork, etc., are "frequently" used. This result suggests teachers' intention to provide students' active participation in the learning process, and to be able to experience, and visualize the contents worked.

However teaching strategies such as "portfolio", "workshop", "panel discussion, forum, symposium", "technical visits", "texts studies", "conceptual maps", "group dynamics", "themes debates", "group discussions activities", "seminars", "simulation", "inquiry-based learning", "case study", "teaching by projects", which presupposes an active participation of the student by developing activities under the guidance of the teacher, and that have as main objective the development of the ability to study and analyze, to synthesize, and to participate in discussions, debates and the exchange of ideas, so necessary to current professional practices, are strategies are "few times" or "never" used, as can be seen in Table 3. Freire \& Schor (1986, p. 57) reported that "teachers see in their own preparation so few good class discussions that they avoid testing their own ability as leaders of discussions". The authors also point out that students, in turn, are conditioned to be passive when the teacher starts a lecture, which ends 
up constituting a trap for the modality of classes in which the discussion is intended. At the other extreme, discussions and debates can "heat up" and embarrass many teachers who, in this way, feel more secure by continuing to give lectures to convey the content of their subject matter.

\section{Qualitative Phase}

The main results of the qualitative phase of the study related to teaching strategies are presented below. The participants of the qualitative phase were 17 teachers selected purposefully. Table 3 shows the demographic characteristics of the sample. For the identification of the interviewees, the code I (interviewed) was used, followed by a number from 1 to 17 , according to the chronological order in which the interviews took place.

\begin{tabular}{llr} 
Table 3 - Demographic characteristics of the qualitative sample \\
\multicolumn{1}{c}{ Item } & \multicolumn{1}{c}{ Category } & $\begin{array}{c}\text { Qualitative } \\
\text { Phase } \\
\text { (n=17) }\end{array}$ \\
\hline \multirow{2}{*}{ Campus } & Campus 1 & $9(53 \%)$ \\
& Campus 2 & $5(29 \%)$ \\
Gender & Campus 3 & $3(18 \%)$ \\
& Female & $4(24 \%)$ \\
Career Stage & Male & $13(76 \%)$ \\
& Early Career (5 years or less) & $5(29 \%)$ \\
& Mid Career (6 to 12 years) & $5(29 \%)$ \\
Kind of Degree & Late Career (13 years or more) & $7(42 \%)$ \\
& Engineering & $16(94 \%)$ \\
\multirow{2}{*}{ Academic Qualification } & Technology & $1(6 \%)$ \\
& Undergraduated & $3(18 \%)$ \\
& Master Degree & $2(11 \%)$ \\
& Doctorate Degree & $12(71 \%)$ \\
\hline
\end{tabular}

Initially we asked participants to describe "how they developed their classes with students". The strategies mentioned by the teachers were: "lecture", "dialogic lecture" and "exercise solving". In order to probe for more detailed explanation this question was followed by an additional question: "how do you use these teaching strategies in your classes?"

In relation to the "dialogic lecture", twelve (12) out of seventeen (17) teachers reported that "chat" prevails in the classroom, with frequent exchange of information between them and students. This is clear in the I1 report, and it illustrates the opinion of the other teachers:

My classes are usually dialogic. What I do is a chat. This is a way of working the class that I realize extends students' learning possibilities. The students end up losing some of the fear and end up asking. I say: "Look, ask, ask what's pertinent. That doubt of yours may be the doubt of the colleague who is ashamed to ask and sometimes, your question is the hook for the other colleague to ask" (I1, Civil Engineer).

For this teacher, the dialogic lecture is a good strategy to involve students and to promote greater connection with the activities developed in class, and consequently, to increase participation. In addition, this strategy allows the teacher to identify if the students understand the content and take back points that needed reinforcement or clarification.

Five (5) respondents, however, reported that their classes were predominately "lectures", because although they try to stimulate student participation, depending on the class and 
subject matter being developed, dialogue does not always happen. The I15 account illustrates teachers' opinion,

So, conquering the students so they talk to me is a challenge. It's something that I wish there were more, but this does not happen. It happens, but it's a tricky business to do. There are classes that let the students more loose and you can, but it's difficult (I15, Computer Engineer).

The participants' opinion regarding "dialogic lecture" make it clear that most teachers seek to develop classes in which the exchange of information and dialogue is established. However, when they fail to do so, teachers opt for "lectures", so characteristic of the traditional pedagogy. By using this strategy, they ensure that the content provided in the teaching plan of the subject matter is transmitted.

The teaching strategy "exercise solving" was mentioned by all the seventeen (17) interviewees as classroom activity, but through exercise lists. Teachers' reports have also shown that the way they propose this strategy requires more than the simple application of rules, formulas, equations and processes already known. This issue is exemplified in the I2 report below:

I do the calculation manually, and then I show that it's not just to do the math, it's not just adding $2+2+2+2$. You have to make decisions before you do the calculation. So I'm doing this with the subject matter of refrigeration. For example: "The minimum volume that was requested here was $100 \mathrm{~m}^{3}$. So you calculate a box of this size. How are you going to put this stuff there? I need a forklift. I need someone to carry. Wait, if I have a forklift, I have to have a moving area of it. Ah, then wait there, it's got bigger. "Wow, but it's almost double the size?" "Yes. Now it has increased the size of the chamber and such" (I2, Mechanical Engineer).

What is understood as "exercise solving" by teachers often demands cognitive abilities such as the ability to analyze, establish relationships, creativity and decision making, which are superior to the automated application of rules and formulas. In this sense, the activities developed do not correspond to what is known and advocated by several authors (Clement \& Terrazzan, 2011; Conceição \& Gonçalvez, 2003; Echeverría \& Pozo, 1998).

In addition to describing the teaching strategies discussed above, we also asked teachers to report how they used the following strategies: "problem-based learning", "practical classes", "teaching by project" and "virtual learning environments".

In relation to "problem-based learning", all teachers interviewed (17) considered that they use this strategy, since solving problems is an inherent activity of the engineering professional. However, although the participants considered that they use it, this does not correspond to what is suggested in the higher education didactic literature as "problem-based learning". This strategy presupposes the involvement of the student in the identification, analysis and solution of real problems proposed by the teacher or identified by the students themselves. Only eight (8) out of the seventeen (17) interviewees mentioned that used the strategy in this way. The I6 report, below, exemplifies how these eight teachers use it:

I asked students to bring problems from their companies and then propose solutions using the quality management tools we had in class. So they had to propose the solution to a problem there in the company. Some students brought real problems and the company adopted the solution to the problem they presented. After they gave a presentation, and debated (I6, Electrician). 
The results showed different ways of understanding "problem-based learning". On the one hand, all teachers have stated that they use it, but in fact, many use other teaching strategies that also involve student in problem solving, usually on a smaller scale. Regarding "practical classes", ten (10) out of seventeen (17) interviewees described them as classes in which students apply concepts and methods studied through participation in challenges, solving calculations, elaboration and execution of projects, seminars, among other activities. The I 1 report is an example of the opinion of these teachers about the issue:

Practical class for me is everything that can deepen, and so to say, establish the knowledge in students' head. So, since a class that you develop an exercise, for me is a practical class. He [the student] is practicing. Look, this is a real exercise. This data is real! So let's practice, let's see how it develops. Of course, the lab is still a practical lesson, so that knowledge is more profitable and the field class too. I see this as being a practical class (I1, Engineer Cartographer).

In this perspective, other teaching strategies such as "problem solving", "problem-based learning", "teaching by project", "seminars", "field study", "simulations", "technical visits", and "discussions and debates" are considered by the interviewees as "practical classes".

This way of understanding these strategies is identified with the provisions of the Curriculum Guidelines for the Training of the Engineer in Brazil (CNE, 2002). This document establishes objectives for the training of engineers that indicate the practice of calculation, analysis, creation, among others, as activities that constitute general skills and abilities for the exercise of the profession of the engineer, that is, professional practices.

The other seven (7) teachers understand that "practical classes" are activities linked to laboratories and equipment (teaching kits, simulators, materials) or carried out in specific environments (visit to companies, physical spaces, etc.) through demonstration of the teacher or student participation, observing, manipulating materials or operating equipment. The I4 report is an example of this understanding:

They are classes using didactic kits that have the purpose of promoting the practice of the contents worked in a theoretical way, through the use of prototypes, the use of devices, components, which serve, for example, to form a system that explains how they function when properly integrated (I4, Electrical Engineer).

This way of understanding the strategy is in line with what is proposed as a "practical lesson" by several authors (Gil, 2013, Madeira \& Silva, 2015; Veiga, 1991; Wilber, 1966) who define it as activities carried out in laboratories or in other specific environments for the demonstration of theories, performance of procedures, use of equipment, etc.

These differences in how the "practical class" is understood at first glance may seem insignificant, but they reveal the lack of consensus around a didactic aspect that can have implications for the engineer's training. The "practical class" is the only teaching strategy that, in most of the subject matters, has an expected workload to be fulfilled and specified in the courses projects, which reveals its importance in the training context of the engineering professional. However, evidence has shown that, despite the importance attached to this strategy, teachers have different ways to understand what constitutes "practice" in the context of engineering training. These raises doubts as to whether the objectives set for this training, related to practical experiences, are being sought.

In relation to the strategy "teaching by projects", ten (10) out of seventeen (17) participants in the study answered that they use it. However, teachers' reports also indicated different ways of 
understanding and the way they use it. For eight (8) respondents, this strategy consists of teaching the student to develop projects or parts of engineering projects, in other words, they confuse the strategy with "engineering design". The I1 report, below, summarizes teachers' understanding about the strategy:

This question of "teaching by projects" is for you to bring, for example, a situation to do, to design an allotment. So this is a way for you to do, teach the basics to the student how to solve the work by project. "Look, I'm going to learn how to do a survey with the purpose of doing an allotment. How do I do it? What do I have to follow? How do I go to the field? How do I do this in the field? "(I1, Engineer Cartographer).

Again we can see the closeness between the concepts coming from the area of teacher training and the way they understand and use these teaching strategies. Another way of understanding and using the "teaching by projects" strategy, reported only by two (2) teachers, refers to activities in which students are involved in experiences in real situations, such as: analysis, elaboration of interventions proposals and the intervention itself. The activity reported by I6 exemplifies this understanding:

I gathered about 120 students in an asylum. An asylum here in [...] with about 90 seniors citizens. I gathered all my classes. We renovated the electrical installations on a weekend. Then everything went: design, electrical part. On another weekend we had a party. So the seniors stayed all day with the students. Then we went to other ladies' home. There were about 200 old people there and the students in the middle, you what I mean? Then the students began to see: "Life, society". There was a student who had never seen an asylum, as how it is to be old. And there you see concept of engineering, project, quality, from the quality of life. And then things start to close. That's what makes the difference (I6, Electrical Engineer).

The way to develop the strategy "teaching by projects", mentioned by the interviewee above, corresponds to what numerous authors (Godoy, 2009; Martins, 1985; Masetto, 2003; Nérici, 1977; Piletti, 1986) define as an activity that intends to address or solve real problems and/or situations, so that the student is involved in the analysis of the situation, in the elaboration of intervention proposal and in the execution of the project.

In relation to "virtual learning environments", teachers' reports show that features such as email, storage services and the provision of personal files and pages are widely used. Sixteen (16) out of the seventeen (17) teachers interviewed reported that they use them to facilitate communication between teacher and students and to provide teaching or support material. The report from I5, below, clarifies how these teachers use some resources:

In fact, it's like this: I use the Moodle. It has the course page in the Moodle. This is the virtual environment. And I use more as a repository. I put all the content taught: the Teaching Plan is there also. If I need to talk to them (students), my office hours are there too. From there weekly I put the content given, because sometimes, we do not follow the Teaching Plan. So for those who missed the lesson: "this was seen, this and that". Then if you want to study, it's there. I put the lists of exercises. If you need to send a message, I'll send it by Moodle. I put proof notice: "the evaluation will be on the Xth day". I put the notices there. I use it more like that (I5, Civil Engineer).

The organization, storage, availability of electronic files and communication with students provided by these resources were considered as "life-enhancing" benefits for both students and teachers, in view of documents available and agility in communication. Only one (1) of the seventeen (17) respondents reported that he does not use information and communication 
technology resources to provide material or communication with students. Let's look at the I8 report:

I do not use it. It's just that. I've tried it and it's not efficient, you know. Well, let's put it like that, the number of questions which come in my email is virtually zero. Last semester, for example, I took a certain exercise, resolved, scanned and emailed to the students. Nobody understood the solution. This is so, because you need a sequence. There in the figure things appear the same as this page, all words are here. Now, if this depends on a logical sequence to be determined, there is no way! (I8, Electrical Engineer).

For this teacher, the computerized resources do not extend the communication between teacher and students nor contribute to the teaching-learning process, since they do not replace the explanation of the teacher, so necessary to show the details and to clarify complex processes. Only two (2) of the seventeen (17) teachers interviewed reported the use of technological resources such as websites and blogs. Let's see how I6 uses these features in its classes:

I work a dynamic where I put some conditions of life, for example: the undergraduate student has a minimum wage, an engineering salary, managed to receive an " $\mathrm{x}$ " value and have to choose a property. Then he will research the property. It goes on sites researching real estate and real estate. And then the groups choose real estate. But I want them to choose properties with attributes. What are attributes? Is to choose properties with 3 bedrooms, have pharmacy near, etc. Then I can get into the concept. But they have to have this access to information technology to be able to search, to enter websites. And then you bring a lot of other things, like urban zoning and public transportation. I could give a definition in 5 minutes, but the student would forget at the end of the class. These resources allow the teacher to exemplify in much more depth the concept he is conveying to the students. I think this is the big thing (I6, Electrical Engineer).

For the interviewee, the use of websites and blogs has produced good effects in order to provide in-depth understanding in the content discussed in the classroom and in the motivation of the students. Regarding to other teaching strategies identified in the questionnaire in the first phase of the study, the reports show that strategies such as "case study", "field study", "seminars", "themes debate", "group debates", "texts study", are used eventually. "Inquire-based learning" is understood as the simple search for information about techniques, norms, data, and information for problem solving or project elaboration. The other strategies, in general, are not used because they are not considered appropriate to the content of the subject matter taught or because the teachers do not know them or master their use. The next session brings the integration of the quantitative and qualitative results of the study.

\section{INTEGRATION OF QUANTITATIVE AND QUALITATIVE RESULTS}

While the questionnaire used in the quantitative phase provided the identification of which were the strategies most used by teachers, the qualitative phase provided an in-depth understanding of why and how these strategies were used. The results obtained in the quantitative study showed that the most used teaching strategies were: "lecture" and "dialogic lecture". In the qualitative phase, the same teaching strategies were mentioned by the teachers as the most used. However, by examining in-depth of how these teaching strategies were used it was possible to perceive two important aspects.

The first aspect refers to the different ways of understanding and applying the following strategies: "exercise solving", "problem-based learning", "practical classes" and "teaching by 
projects". These differences reveal the lack of uniformity, consensus among teachers, about teaching strategies, which are tools that are supposed to be used in a daily basis. The second aspect concerns the relationship between concepts from the engineering area and how to understand and apply "practice class" and "teaching by projects", which suggests the influence of the training area of the majority of teachers interviewed.

Related to the use of "virtual learning environments", the two phases of the study showed that they are mainly used to make materials available and communication with students. In addition, the qualitative findings showed that teachers seek the development of classes in which the dialogue between them and students prevails, that is, students are actively involved in the activities developed and that these activities require the students cognitive aspects such as the ability to analyze, establish relationships, creativity and decision-making. These practices suggest the adoption of some principles of active methodologies. A summary of the main results obtained in the quantitative and qualitative phases of the study on teaching strategies are presented in Table 4, below:

Table 4 - Results of the quantitative and qualitative phases of the study related to the most used teaching strategies

\begin{tabular}{|c|c|c|}
\hline Teaching Strategies & $\begin{array}{c}\text { Quantitative Phase } \\
\text { (\% responses } \\
\text { "frequently" and "always) }\end{array}$ & $\begin{array}{c}\text { Qualitative Phase } \\
\text { (How teachers use the strategy) }\end{array}$ \\
\hline $\begin{array}{l}\text { Virtual Learning } \\
\text { Environments }\end{array}$ & $84 \%$ (168) & $\begin{array}{l}\text { Virtual learning environments are mainly used } \\
\text { for communication, and provision of teaching } \\
\text { and support material to the students }\end{array}$ \\
\hline Lecture & $76 \%(152)$ & $\begin{array}{l}\text { Classes are only based on lectures, prevailing } \\
\text { the transmission of the content by the teacher }\end{array}$ \\
\hline Dialogic Lecture & $75 \%$ (149) & $\begin{array}{l}\text { There are moments of content exposure, but } \\
\text { "chat" prevails, with frequent exchange of } \\
\text { information between teacher and students }\end{array}$ \\
\hline Exercise Solving & $74 \%(147)$ & $\begin{array}{l}\text { The solved exercises go beyond the application } \\
\text { of rules, formulas, equations and processes } \\
\text { already known. They also demand cognitive } \\
\text { abilities superior to the automated application } \\
\text { of rules and formulas, such as the capacity for } \\
\text { analysis, relationship building, creativity, } \\
\text { decision making }\end{array}$ \\
\hline $\begin{array}{l}\text { Executive Practical } \\
\text { Class }\end{array}$ & $70 \%(140)$ & $\begin{array}{l}\text { Moments in which students apply concepts and } \\
\text { methods studied during the course, through } \\
\text { various activities such as participation in } \\
\text { challenges, problem solving, problem solving, } \\
\text { project preparation and execution, presentation } \\
\text { of seminars, observation and verification of } \\
\text { equipment and environments, among others. }\end{array}$ \\
\hline $\begin{array}{l}\text { Problem-Based } \\
\text { Learning }\end{array}$ & $65 \%(130)$ & $\begin{array}{l}\text { Encouraged discussions in the classroom and } \\
\text { solving calculations. Activities in which the } \\
\text { student engages in the identification, analysis } \\
\text { and elaboration of proposals for real problems } \\
\text { suggested by the teacher or identified by the } \\
\text { students themselves. }\end{array}$ \\
\hline $\begin{array}{l}\text { Demonstrative } \\
\text { Practical Class }\end{array}$ & $52 \%(103)$ & $\begin{array}{l}\text { A variety of activities are promoted, in which } \\
\text { students are involved in problem solving, } \\
\text { project preparation, application of concepts } \\
\text { worked in the classroom }\end{array}$ \\
\hline Teaching by Projects & $49 \%(98)$ & $\begin{array}{l}\text { Development of projects or parts of engineering } \\
\text { projects }\end{array}$ \\
\hline
\end{tabular}




\section{CONCLUSIONS}

The purpose of this article was to identify the teaching strategies most used by teachers of undergraduate engineering courses at a university in southern Brazil. The main results indicates the still predominant position of the "lecture" and the "dialogic lecture" as the most used strategies, and the need for a more varied usage of strategies and procedures enabling students to be more active and to assume greater liability in their own educational process.

The results of the quantitative phase showed that teachers frequently use strategies such as "executive practical classes", "problem-based learning", "demonstrative practice class", and "learning by projects". These results may indicate a positive movement in the reorganization of university teaching process, however, the results in the qualitative phase showed that teachers have a different understanding and ways of applying these strategies. It was also identified that "virtual learning environments" are widely used, but mainly, for communication with students and availability of materials, without exploiting the potential that these resources offer for teaching. From a general perspective, the most used teaching strategies are those that go back to the traditional pedagogy, in which the process and contents are centered on the teacher, with little students' participation.

The fact that other strategies that promote active learning and recognize different needs of individual students, asking them to assume liability for personal learning and promoting critical thinking and independent learning such as "technical visits", "games", "portfolios", "concept maps" etc. are not used and sometimes not understood by teachers show a gap in teachers' initial and continuing preparation.

There are practical implications for teachers and for the institution's managers. Teachers need to engage in the search for more knowledge about teaching strategies that enable them to respond to the dynamics of the new generations through stimulating activities that provide students with experience, involvement and motivation. The need for teachers to improve their knowledge about teaching strategies is clear. The results have shown that strategies proposed by active learning are practically unknown to teachers despite being studied, discussed and disseminated not only in the area of didactics of higher education, but also in the area of engineering education.

It is also important to highlight the need for teachers to improve their knowledge about the use of new technologies as teaching and learning resources. Virtual learning environments (e-mail, websites, blogs, social networks, etc.) that have the potential to help motivation, increase active participation of students and improve learning, are mainly used within an instrumental perspective, for the establishment of communication between teachers and students and as a repository of teaching or support material. Thus, teachers are the leaders of these changes who must be able to implement various different teaching methods and procedures and to alternate them strategically encouraging creativity, problem solving, and experience-based learning.

As for the institution's managers there is a need to create mechanisms to support teachers to master the didactic-pedagogical issues. One proposal of action in this sense is the creation of Insertion Programs for Beginners Teachers. Other is the creation of programs of continuing education focused on didactic-pedagogical issues. For Souza (2013), continuing education in higher education seeks to leave teachers in a position to re-evaluate and re-elaborate their knowledge built with practice. This training is intended to disturb teachers so that they can observe their actions, analyze whether what is being developed is leading to satisfactory results for the teacher and the students and to verify what needs to be changed to improve the learning process. 


\section{References}

Abreu, M. C. T. A. D.; Masetto, M. (1980), O professor universitário em aula: prática e princípios teóricos, São Paulo: Cortez, Coleção Educação Contemporânea.

Anastasiou, L. D. G. C. (1998), Metodologia do Ensino Superior: da prática docente a uma possível teoria pedagógica, Curitiba: IBPEX Autores Associados.

Anastasiou, L. D. G. C. (2001), Metodologia do ensino na universidade brasileira: elementos de uma trajetória. In: Castanho, S.; Castanho, M. E. Temas e textos em metodologia do ensino superior, Campinas: Papirus, p. 57-70. Coleção Magistério: Formação e Trabalho Pedagógico.

Anastasiou, L. D. G. C.; Alves, L. P. (2006), Processos de ensinagem na universidade: pressupostos para as estratégias de trabalho em aula. 6. ed. Joinvile: UNIVILLE.

Angelo, M. F. et al. (2014), Aplicação e avaliação do método PBL em um componente curricular integrado de programação de computadores, Revista de Ensino de Engenharia, v. 33, p. 31-43, http://198.136.59.239/ abengeorg/revista/index.php/abenge/article/view/245/190, Acessed 7th August 2017.

Barbosa, E. F.; Moura, D. G. (2013), Metodologias ativas de aprendizagem na educação profissional e tecnológica, Boletim Técnico do Senac, 39, n. 2, maio/agosto, p.48-67.

Bazzo, W. A.; Pereira, L. T. D. V.; Linsingen, I. V. (2000), Educação Tecnológica: enfoques para o ensino de engenharia, Florianópolis: UFSC.

Belhot, R. V. (2005), A didática no ensino de engenharia, 33o Congresso Brasileiro de Engenharia - COBENGE. Campina Grande: [s.n.].

Bonwell, C. C.; Eison, J. A. (1991), Active learning: creating excitement in the classroom, ASHE-ERIC Higher Education Report, Washington D.C., ISSN 1. https://files.eric.ed.gov/fulltext/ED336049.pdf, Acessed 27th May 2018.

Broilo, C. L. (Con)formando o trabalho docente: a ação pedagógica na universidade. In: Leite, D.; Genro, M. E. H.; Braga, A. M. E. S. Inovação e pedagogia universitária. Porto Alegre: Editora da UFRGS, Cap. 10, p. 256.

Campos, L. C. D. et al. (2012), Aprendizagem Baseada em Projetos: uma nova abordagem para a educação em engenharia, In: Oliveira, V. F. D., et al. Desafios da educação em engenharia: vocação, formação, exercício profissional, experiências metodológicas e proposições, Blumenau: ABENGE / EdiFURB, cap. IV, p. 115-162.

Carvalho, A. C. B. D. D.; Porto, A. J. V.; Belhot, V. (2001), Aprendizagem significativa no ensino de ngenharia de Produção, p. 81-90, http://www.scielo.br/pdf/prod/v11n1/v11n1a06.pdf, Acessed 20th June 2014.

Castanho, M. E. L. M. (2000), Professores e inovações. In: CASTANHO, S.; CASTANHO, M. E. 0 que há de novo na educação superior: do projeto pedagógico à prática transformadora. Campinas: Papirus, Cap. 3, p. 75-94. Coleção Magistério: Formação e Trabalho Pedagógico.

Charmaz, K. (2000), A construção da teoria fundamentada [recurso eletrônico]: guia prático para análise qualitativa.. Porto Alegre: Artmed, 2009.

Chickering, A. W.; Gamson, Z. F. (1987), Seven principles for good practice in undergraduate education, AAHE Bulletin, p. 3-7, http://files.eric.ed.gov/fulltext/ED282491.pdf, Acessed 29th September 2015.

Clement, L.; Terrazzan, E. (2011), A. Atividades didáticas de resolução de problemas e o ensino de conteúdos procedimentais, Revista Electrónica de Investigación em Educación en Ciencias, v. 6, n. 1, p. 87-101, http://ppct.caicyt.gov.ar/index.php/reiec/issue/view/460, Acessed 26th May 2018.

CNE (2018), Conselho Nacional de Educação, Resolução CNE/CES 11, de 11 de março de 2002, Diretrizes Curriculares Nacionais do Curso de Graduação em Engenharia. [S.l.].

Conceição, K. D.; Gonçalvez, M. B. (2003), A resolução de problemas no processo ensino-aprendizagem de matemática nos cursos de engenharia, Anais do 31ํㅡㄹ Congresso Brasileiro de Educação em Engenharia. Rio de Janeiro: [s.n.].

Creswell, J. W. (2003). Research design, Qualitative, quantitative and mixed methods approaches (2nd ed.), Thousand Oaks, CA: Sage.

Creswell, J. W., Plano Clark, V. L., Gutmann, M. L. \& Hanson, W. E. (2003). Advanced mixed methods research designs, In: A. Tashakkori and C. Teddlie (Eds), Handbook on mixed methods in the behavioral and social sciences,p. 209-240, Thousand Oaks, CA: Sage Publications.

Creswell, J. W.; Plano Clark, V. L. (2013), Pesquisa de métodos mistos, 2. ed. Porto Alegre: Penso. 
Echeverría, M. P. P.; Pozo, J. I. (1998), Aprender a resolver problemas e resolver problemas para aprender. In: Pozo, J. I. A solução de problemas, Porto Alegre: Artes Médicas.

Freire, P.; Schor, I. (1986), Medo e ousadia: o cotidiano do professor, 4. ed. Rio de Janeiro: Paz e Terra.

Ghelli, G. M. (2004), A construção do saber no ensino superior, Cadernos da Fucamp, v. 3, n. 3, http://www.fucamp.edu.br/editora/index.php/cadernos/article/view/57, Acessed 21st November 2014.

Gil, A. C. (2013), Didática do ensino superior, São Paulo: Atlas.

Godoy, A. C. D. S. (2009), Fundamentos do trabalho pedagógico, Campinas: Alínea.

Godoy, A. S. (2000), Avaliação da aprendizagem no ensino superior: um estudo exploratório a partir das opiniões dos alunos do primeiro e do último ano de três cursos de graduação, Administração On Line: Prática, Pesquisa, Ensino, v. 1, n. 1, http://www.fecap.br/adm_online/art11/arilda.htm, Acesseed 23rd March 2015.

Gonçalves, S. (2008), Estilos de aprendizagem e ensino. In: GONÇALVES, S. Pedagogia no ensino superior. 3. ed. [S.l.], Escola Superior de Educação de Coimbra. Cap. 1, p. 7-22, http://ndsim.esec.pt/pagina/opdes/brochuras/03.pdf, Acessed 11th November 2014.

Greene, J. C., Caracelli, V. J. and Graham, W. F. (1989), Toward a conceptual framework for mixed-method evaluation designs, Educational Evaluation and Policy Analysis, v. 11, (3), p. 255-274.

Johnson, B. and Turner, L.A. (2003), Data Collection Strategies in Mixed Methods Research. In: Tashakkori, A.M. and Teddlie, C.B., Eds., Handbook of Mixed Methods in Social and Behavioral Research, SAGE Publications, Thousand Oaks, p.297-319.

Leite, F. (2015), Raciocínio e procedimentos da Grounded Theory Construtivista. Questões Transversais, Revista de Epistemologias da Comunicação, p. 76-85,

http://revistas.unisinos.br/index.php/questoes/article/view/11310. Acessed 2nd March 2017.

Madeira, M. C.; Silva, R. M. A. D. (2015), Ensinar na universidade: didática para professores iniciantes, Petrópolis: Vozes.

Martins, J. D. P. (1985), Didática Geral: fundamentos, planejamento, metodologia, avaliação, São Paulo: Atlas.

Masetto, M. T. (2003), Competência pedagógica do professor universitário, São Paulo: Summus.

Morais, M. D. F. D. (2009), A utilização de métodos participativos no ensino de engenharia de produção: o caso do curso de engenharia de produção agroindustrial da Fecilcam. IV EPCT - Encontro de Produção Científica e Tecnológica. [S.l.]: [s.n.].

Moreira, H. et al. (2015), Pedagogical Practice in Engineering Courses: student's contribution, International Journal of Education, v. 7, n. 2, p. 293-305, http://www.macrothink.org/journal/index.php/ije/article/view/7503/6440, Acessed 1st October 2015.

Moreira, H.; Caleffe, L. G. (2008), Metodologia de pesquisa para o professor pesquisador, 2. ed. Rio de Janeiro: Lamparina.

Moreira, H.; Gravonski, I.; Aranda, A. (2012), As percepções dos alunos de engenharia sobre as práticas de avaliação da aprendizagem, Revista Iberoamericana de Evaluación Educativa, v. 5, n. 3, p. 275-290, http://www.rinace.net/riee/numeros/vol5-num3/art16.html, Acessed 28th September 2015.

Nassif, L. (2013), O desafio de formar engenheiros no Brasil, Carta Capita, http://www.cartacapital.com.br/sociedade/o-desafio-de-formar-engenheiros-no-brasil, Acessed 11 th June 2014.

Nérici, I. G. (1977), Metodologia de Ensino: uma introdução, São Paulo: Atlas.

Pereira, A. T. C.; Schmitt, V.; Dias, R. Á. C. (2007), Ambientes virtuais de aprendizagem, [S.l.]: Ciência Moderna, http://pucrs.br/famat/viali/tic_literatura/artigos/ava/2259532.pdf, Acessed 27th November 2015.

Piletti, C. (1986), Didática geral, 6. ed. São Paulo: Ática.

Sampieri, R. H.; Collado, C. F.; Lucio, M. D. P. B. (2013), Metodologia de Pesquisa, 5. ed. Porto Alegre: Penso.

Silva, L. P.; Cecílio, S. (2007), A mudança no modelo de esnino e formação na engenharia, Educação em Revista, Belo Horizonte, v. 45, p. 61-80, http://scielo.br/pdf/edur/n45/a04n45.pdf, Acessed 22nd June 2014.

Tashakkori, A. \& Teddlie, C. (2003), Handbook of Mixed Methods in Social \& Behavioral Research, Thousand Oaks:Sage.

Veiga, I. P. A. (1991), Na sala de aula: o estudo dirigido. In: Veiga, I. P. A. Técnicas de ensino: por que não? Campinas: Papirus, p. 67-88. Coleção Magistério: Formação e Trabalho Pedagógico. 
Villas-Boas, V. et al. (2012), Aprendizagem ativa na educação em engenharia. In: Oliveira, V. F. D., et al. Desafios na educação em engenharia: vocação, formação, exercício profissional, experiências metodológicas e proposições, Brasília / Blumenau: ABENGE/EDIFURB, Cap. 3, p. 59-114.

Wilber, G. O. (1966), As artes industriais na educação geral, Rio de Janeiro; São Paulo: Livraria Freitas Basto. 